\title{
Currículo e Relações Étnico-Raciais: o Estado da Arte ${ }^{1}$
}

\section{Curriculum and Ethnic-Race Relations: a Review}

\author{
Kátia Regis* \\ Guilherme Basílio**
}

\begin{abstract}
RESUMO
Este artigo apresenta a sistematização e a análise dos 38 artigos, 13 teses e 50 dissertações da Categoria Currículo. Inicialmente, demonstraremos os resultados do exame das teses e das dissertações. Em seguida, refletiremos acerca dos artigos. Para a leitura e análise dos artigos e da produção discente, utilizamos como subsídio os referenciais da análise de conteúdo, por meio da análise categorial (BARDIN, 2008). Ao final, apresentaremos os caminhos abertos para pesquisas futuras e as recomendações da produção investigada para a implementação da Lei no 10.639/2003.
\end{abstract}

Palavras-chave: Currículo. Relações étnico-raciais. População negra.

\begin{abstract}
This article presents the systematization and analysis of the 38 papers, 13 theses and 50 dissertations about of curriculum and race relations. Initially, we will demonstrate the results of the examination of the theses and dissertations. Then, we will reflect on the articles. For the reading and
\end{abstract}

1 Pesquisa financiada pelo Conselho Nacional de Desenvolvimento Científico e Tecnológico (CNPQ), Coordenação de Aperfeiçoamento de Pessoal de Ensino Superior (CAPES), Fundação Araucária e Secretaria de Educação Continuada, Alfabetização, Diversidade e Inclusão do Ministério da Educação (SECADI/MEC).

${ }^{*}$ Universidade Federal do Maranhão. São Luís, Maranhão, Brasil. Av. dos Portugueses, 1966. Vila Bacanga. CEP: 65080-580. E-mail: katia_educ@yahoo.com.br. ORCID: https://orcid. org/0000-0002-4104-1963

** Universidade Pedagógica de Moçambique. Faculdade de Ciências Sociais e Filosóficas. Maputo, Moçambique. Rua João Carlos Raposo Beirão n ${ }^{\circ}$ 135. Caixa Postal n 3276. E-mail: guilhermebasilio@yahoo.com.br. ORCID: https://orcid.org/0000-0001-9476-4324 
analysis of the articles and the student production, we use the content analysis framework through categorical analysis. At the end, we will present the open paths for future research and the recommendations from the investigated studies for race relations education in Brazil (implementation of 10.639 / 2003 Law.

Keywords: Curriculum. Ethnic-race relations. Black population.

\section{Introdução}

O currículo é uma construção sistemática de conhecimentos socializado pelas instituições escolares e o contexto social, econômico, político e cultural que ele representa, ou deixa de retratar, deve ser o primeiro aspecto para analisá-lo e avaliá-lo. O currículo real é uma opção entre alternativas; não é algo neutro e fixo, mas um campo controverso no qual são realizadas escolhas que não são as únicas possíveis. (SACRISTÁN, 1998, 2013). Mas, o que é considerado valioso para integrar os currículos escolares e o que é desconsiderado? $\mathrm{O}$ conhecimento corporificado nos currículos tem sido predominantemente eurocêntrico. No Brasil, as críticas ao currículo eurocêntrico foram impulsionadas após a promulgação da Lei $n^{0} 10.639 / 2003^{2}$, que tornou obrigatório o ensino da História e Cultura Africana e Afro-Brasileira. Este texto apresenta a sistematização e a análise dos 38 artigos, 13 teses e 50 dissertações da Categoria Currículo. Inicialmente, demonstraremos os resultados do exame das teses e das dissertações. Em seguida, refletiremos acerca dos artigos. Para a leitura e análise dos artigos e da produção discente, utilizamos como subsídio os referenciais da análise de conteúdo, por meio da análise categorial (BARDIN, 2008). Ao final, apresentaremos os caminhos abertos para pesquisas futuras e as recomendações da produção investigada para a implementação da Lei n 10.639/2003.

\section{Análise das teses e dissertações}

Para a sistematização e análise das pesquisas consideramos os seguintes aspectos: objetivo; referencial teórico; metodologia; nível, etapa e modalidade

2 A Lei ${ }^{\circ}$ 11.645, de 10 de março de 2008, altera a LDB 9394/96, anteriormente modificada pela Lei no 10.639 , para incluir no currículo oficial da rede de ensino a obrigatoriedade da temática "História e Cultura Afro-Brasileira e Indígena". 
de ensino; sujeitos envolvidos; principais resultados e recomendações das teses e das dissertações para a implementação da Lei $n^{0} 10.639 / 2003$. Encerrada a leitura da produção discente, dividimo-las em cinco subcategorias a partir do principal foco de discussão dos(as) autores(as) e de seus resultados:

a) o ensino da História e Cultura Africana e Afro-Brasileira;

b) currículo na ação;

c) relações étnico-raciais e Currículo;

d) diversidade étnico-racial e Currículo e

e) outros temas.

A produção de teses e dissertações defendidas entre 2003 e 2014 na Categoria Currículo concentra-se nas regiões Sudeste (35 pesquisas) e Nordeste (22 produções) do país, com um maior número de produções acadêmicas realizadas em São Paulo (19 pesquisas), Bahia (13 pesquisas), Minas Gerais (08 investigações) e Rio de Janeiro (08 trabalhos).

Um primeiro aspecto que podemos mencionar refere-se ao referencial teórico utilizado nas pesquisas: os(as) autores mais utilizados para a discussão acerca das relações étnico-raciais no Brasil são Kabengele Munanga, Petronilha Beatriz Gonçalves e Silva e Nilma Lino Gomes, seguidos de Eliane Cavalleiro e Antônio Sérgio Alfredo Guimarães. Os(as) autores(as) mais usados para a reflexão sobre currículo são José Gimeno Sacristán, Tomaz Tadeu da Silva e Antônio Flávio Barbosa Moreira. Também são utilizados(as) como aporte teórico para esta discussão Michael Apple, Henry Giroux, Jurjo Torres Santomé, Elisabeth Macedo, Vera Candau e Ana Canen. As reflexões sobre multiculturalismo têm como aporte Peter McLaren e sobre identidade Stuart Hall. Paulo Freire é uma referência constante nas reflexões sobre as práticas educativas.

A produção discente analisada realiza as investigações valendo-se de uma abordagem qualitativa, com a utilização de diferentes metodologias. Há o predomínio da utilização da etnografia (15 pesquisas), análise de conteúdo (7 trabalhos), estudo de caso (4 investigações) e fenomenologia (3 pesquisas).

As instituições educacionais analisadas, geralmente, fazem parte dos sistemas públicos da educação básica, com predomínio das redes municipais (22 trabalhos); 5 trabalhos discutem as redes estaduais. Em relação aos sujeitos participantes da pesquisa e/ou que tiveram suas práticas analisadas, há a preponderância dos professores e das professoras (30 investigações) e estudantes (24 trabalhos). A atuação da equipe gestora foi discutida em 14 pesquisas; em 7 investigações houve a reflexão sobre as ações dos integrantes das Secretarias Municipais e Estaduais de Educação; e a participação da comunidade e/ou dos movimentos sociais foi examinada em 4 trabalhos. Em diversas pesquisas, esses sujeitos aparecem simultaneamente. Em relação às áreas do conhecimento, 
as mais investigadas foram História (8 pesquisas), Matemática (6 trabalhos), Educação Física (5 investigações) e Geografia (3 pesquisas).

\section{O ensino da História e Cultura Africana e Afro-Brasileira}

Essa subcategoria integra as pesquisas que problematizam acerca dos desafios e das possibilidades do ensino da História e Cultura Africana e Afro-Brasileira nos currículos escolares de diferentes áreas do conhecimento: História, Geografia, Filosofia, Língua Portuguesa, Artes, Matemática e Educação Física. Essas ações ocorrem, geralmente, em instituições da educação básica dos sistemas públicos de ensino, envolvendo professores(as), estudantes(as) e gestores(as), com a descrição de como elas ocorreram e os seus resultados. As investigações são as seguintes: Alves (2003), Barros (2011) Caetano (2012), Correia (2014), Costa (2011), Duarte (2006), Fernandes (2012), Goncalves (2012); Machado (2014), Machado (2012), Maranhão (2014), Mattos (2013), Mendonça (2011), Mota (2014), Nicolin (2007), Novaes (2014), Oliveira (2011), Pereira (2011), Santos (2007), Silva (2010), Silva (2006), Silva (2008), Silva Júnior (2010), Simonini (2011), Souza (2008), Souza (2010), Vale (2012).

Com base na leitura dos trabalhos, identificamos diferentes possibilidades de práticas para a inclusão da História e Cultura Africana e Afro-Brasileira, por meio da(o): Capoeira (SILVA, 2006, SILVA JÚNIOR, 2010); Capoeira Angola (VALE, 2012; MACHADO, 2012); Capoeira Angola e Capoeira Regional (GONÇALVES, 2012); Dança Afro-Brasileira (BARROS, 2011); Dança Afro-Brasileira Coco de Zambê (ALVES, 2003); histórias em quadrinhos (DUARTE, 2006); Jogos Africanos Mancala (SILVA, 2010); jogos de origem e/ou descendência africana (MARANHÃO, 2014); jogo de tabuleiro africano Awalé da família do Mancala (PEREIRA, 2010); Jongo (FERNANDES, 2012); Pagode (MATTOS, 2013); Samba (CAETANO, 2012) uso de imagens de África (NOVAES, 2014).

As teses e as dissertações dessa subcategoria realizam proposições acerca do Ensino da História e Cultura Africana e Afro-Brasileira, conforme podemos notar no exemplo a seguir: Pereira (2011) objetivou verificar a possibilidade da utilização do jogo de tabuleiro africano Awalé da família Mancala como metodologia de ensino e de aprendizagem na área da Matemática, da História e da Cultura Afro-Brasileira em duas escolas de ensino fundamental: uma em Vitória (ES) e uma em Cariacica (ES). 
Os trabalhos apontam resultados significativos acerca da inserção da História e Cultura Africana e Afro-Brasileira, como segue: Mattos (2013) constatou que, por meio da dança do pagode, existe a possibilidade de convidar os(as) os estudantes a conhecerem a história das danças e dos ritmos afro-brasileiros; reconhecerem movimentos do candomblé existentes no pagode; identificação dos instrumentos percussivos e dos instrumentos tecnológicos; da plasticidade; as linguagens do corpo para as sociedades africanas e de que forma elas se manifestam no presente. Portanto, pode-se identificar as manifestações culturais Afro-Brasileiras na música e na dança.

Apesar das possibilidades apontadas pela produção analisada, também é recorrente nos trabalhos a reflexão acerca dos desafios para a inclusão da História e Cultura Africana e Afro-Brasileira: Silva Júnior (2010) considera que a inserção da capoeira anteriormente à implementação da Lei $\mathrm{n}^{\circ} 10.639 / 2003$ e da Lei $\mathrm{n}^{0} 11.645 / 2008$ nas instituições que pesquisou foi importante para a divulgação da capoeira na comunidade escolar. Entretanto, com a suspensão da continuidade desses projetos, este papel foi perdido. Destaca também que a implementação da Lei ocorre nas escolas de forma esporádica, por meio de iniciativas isoladas de alguns docentes.

\section{Currículo na ação}

Esta subcategoria integra as pesquisas que versam sobre as práticas curriculares desenvolvidas no cotidiano das instituições educacionais, problematizando a incompatibilidade entre o estabelecido no arcabouço legal e o que ocorre no currículo na ação. Há o destaque de que o ensino da História e Cultura Africana e Afro-Brasileira é realizado, geralmente, por meio de ações pontuais e isoladas.

As pesquisas desta subcategoria revelam a dissociação entre as intenções e a prática curricular: o ensino da História e Cultura Africana e Afro-Brasileira ocorre esporadicamente, com pouco destaque para o ensino da temática, como podemos observar nos exemplos a seguir: para a realização da pesquisa de Sampaio (2013), foram analisadas as aulas de três professores(as) de Língua Portuguesa em turmas do $6^{\circ}$ ano ao $9^{\circ}$ ano em escolas de Matinha dos Pretos (BA). Durante o período os(as) docentes deram pouco destaque para a História e Cultura Africana e Afro-Brasileira. Pereira (2012) constatou que há o conhecimento da Lei pelos(as) professores(as), mas que as temáticas relacionados à questão étnico-racial são abordadas de maneira esporádica e circunstancial e que existe defasagem entre o estabelecido pela legislação e a sua aplicabilidade. 
Fernandes (2011) revela que os trabalhos pontuais com datas comemorativas, como o 13 de maio (Abolição da Escravatura), o 19 de abril (Dia do Índio) e o 20 de novembro (Dia da Consciência Negra) foram muito destacados pelas professoras: algumas fizeram menção a sua importância e outras criticaram a pontualidade do trabalho somente nestas datas na escola. Destaca ainda que, apesar da Secretaria Municipal de Educação de Florianópolis (SC) ter conhecimento sobre o arcabouço legal acerca da temática, a pesquisa revela que isso não garante o efetivo trabalho em sala de aula e que existe uma ausência de engajamento da escola para a garantia de um planejamento de trabalho com a Educação das Relações Étnico-Raciais.

\section{Relações étnico-raciais e Currículo}

Esta subcategoria agrega as investigações que refletem sobre o modo como ocorrem as relações étnico-raciais nas escolas. As pesquisas inclusas nesta categoria são as seguintes: Alves (2013); Amorim (2011); Bento (2012); Crocetta (2014); Cruz (2008); Mello (2006); Oliveira (2008); Soares (2011) e Souza (2005).

As investigações discutem como a lógica eurocêntrica das práticas curriculares perpassa as relações étnico-raciais no cotidiano escolar e acerca do tratamento desigual destinado aos(às) estudantes brancos(as) e estudantes negros(as), interferindo negativamente na trajetória educacional dos(as) estudantes negros(as). A pesquisa de Cruz (2008), que teve como participantes da investigação 14 estudantes do $4^{\circ}$ ano de escola pública municipal de São Carlos, revela, por meio das falas das crianças, as tensões das relações étnico-raciais no cotidiano escolar:

\footnotetext{
$[\ldots]$ conversar como se fosse um branco $[\ldots](\mathrm{p} .85)$

[...] ela não tem culpa de ter nascido assim [...] (p. 87)

[...] porque é ruim ser negro [...] (p. 107)
}

Segundo a autora (CRUZ, 2008), as crianças experienciam o currículo de forma contraditória e conflitante: escutam o discurso da igualdade e vivenciam cotidianamente situações de desigualdades nas relações interpessoais que ocorrem nas escolas e o recorrente discurso vazio ou marcadamente moralista: não pode discriminar. 
Diante dessas situações permeadas por estereótipos, preconceitos e discriminações nas instituições educacionais, demonstradas nas teses e nas dissertações, os(as) autores(as) dos trabalhos ressaltam que, geralmente, ocorre o silenciamento sobre essas, que são encobertas pelo discurso da igualdade abstrata, mas se configuram em desigualdades entre brancos(as) e negros(as). Amorim (2011) contata que a temática tem sido inserida nas propostas e nas práticas curriculares do cotidiano escolar em situações que foram objeto de debates e reflexões e em outras ocasiões foram silenciadas. Apesar da escola não estar alheia ao debate sobre as relações étnico-raciais, nem todos os(as) professores(as) estão atentos para a temática. Entretanto, existe o esforço da Secretaria Municipal de Educação de Recife para oportunizar mudanças no cotidiano escolar, mesmo em meio a muitas dificuldades, pois "A inserção das relações étnico-raciais ocorre com "enfrentamentos, tensões e desacordos" (AMORIM, 2011, p. 263).

\section{Diversidade Étnico-Racial e Currículo}

As pesquisas desta subcategoria refletem sobre a diversidade étnico-racial no currículo. Há o destaque também que, em uma escola homogeneizadora e estruturada a partir da perspectiva do universalismo abstrato, as diferenças são tratadas como desigualdades e de maneira discriminatória.

As pesquisas desta subcategoria são: Costa (2012), Macêdo (2008), Marques (2004), Pereira (2006), Pereira (2013), Soares (2009), Souza (2005), Souza (2011). As pesquisas apontam que as políticas curriculares voltadas para a diversidade estão questionando hierarquias e privilégios na sociedade brasileira, como era de se esperar, e que trazem indagações a uma escola estruturada a partir da lógica da igualdade abstrata. Indagar esta homogeneidade, estabelecida a partir do referencial eurocêntrico nos currículos escolares, para transformá-la, significa suscitar conflitos. Estas questões são discutidas nas pesquisas. Macêdo (2008) discute a influência do currículo escolar na construção da identidade étnico-racial dos(as) educandos(as), em uma escola municipal situada na comunidade negra rural quilombola Araçá/Cariacá, no município de Bom Jesus da Lapa (BA). Os resultados revelam que a instituição educacional demonstra a intenção de trabalhar com a História e a Cultura da comunidade. Entretanto, não consegue questionar e transgredir o currículo oficial e tem dificuldades de romper com as práticas discriminatórias e excludentes. Em decorrência disso, a escola não atende às especificidades étnica e cultural dos(as) estudantes e tende 
a transmitir um currículo monocultural, dificultando o processo de construção da identidade étnico-racial e da autoestima desses(as) educandos(as).

Souza (2005, p. 19) objetivou "realizar uma arqueologia sócio-histórica da Banda de Congo Mirim e sua inserção na Escola Estadual Pluridocente de Ensino Fundamental de Roda d'Água” em (Cariacica/ES). A autora observou, analisou e descreveu e relatou a conduta das as crianças e adolescentes negros(as) da Banda e descreveu como reagem ao serem discriminados(as) por serem negros(as) e congueiros(as). Por meio dos depoimentos das crianças, surgem revelações de como o espaço da Banda propicia a autoestima positiva dos seus participantes: "Quando eu toco congo eu sou a pessoa mais feliz do mundo!" (Maicon Dias Ferreira, Congueiro da Banda de Congo Mirim de Roda d'Água, 10 anos, p. 43). Contudo, há o destaque do silenciamento da escola acerca das especificidades da comunidade. Além disso, ocorre a desconsideração dos(as) docentes em relação ao preconceito e à discriminação racial, que afeta os(as) estudantes, conforme o relato a seguir:

Eu não falo pra todo mundo que eu sou do congo não, elas ficam me chamando de nego preto, macumbeiro [...] E quando me chamam de nego macumbeiro, tocador de tambor eu dou logo uma porrada porque a professora nunca faz nada, às vezes até me coloca de castigo (Tarcisio, 10 anos, $5^{\text {a }}$ série, congueiro da Banda Mirim). (SOUZA, 2005, p. 66).

\section{Outros temas}

Esta subcategoria integram os trabalhos que abordam outras temáticas acerca da Educação para as Relações Étnico-Raciais e para o ensino da História e Cultura Africana e Afro-Brasileira. As pesquisas são as seguintes: Braço (2008), Duli (2014), Mello (2006), Neto (2012), Nogueira (2007), Pinheiro (2013), Pontes (2000), Ramos (2009), Regis, (2009), Rodrigues (2010).

Regis (2009) sistematizou e analisou as principais questões discutidas em teses e dissertações, que enfocaram as Relações Étnico-Raciais e Currículo desenvolvidas em programas de pós-graduação stricto sensu em Educação, entre 1987 e 2006. Pinheiro (2013) problematiza uma prática narrativa popular enquanto processo educativo e de resistência. Pontes (2000) analisa o contexto de produção do texto do Parecer CNE/CP 03/2004, que fundamenta as Diretrizes Curriculares Nacionais para a Educação das Relações Étnico-Raciais e para o Ensino de História e Cultura Afro-Brasileira e Africana. 
Nesta subcategoria três trabalhos abordam o currículo em diferentes países do Continente Africano: Braço (2001) refletiu acerca da educação em Moçambique a partir dos ritos de iniciação da etnia Ma-Sena e a influência na formação das identidades socioculturais, objetivando colaborar com o currículo das instituições educacionais para a inserção dos saberes locais. A pesquisa foi desenvolvida no distrito de Caia, província de Sofala, região central do país. Duli (2014) teve a finalidade de apreender as estratégias utilizadas pelos(as) estudantes na resolução de problemas contextualizados em escola do II Ciclo do Ensino Secundário de Cabinda (Angola). Para tanto, o autor investiga as estratégias utilizadas pelos(as) discentes na resolução de problemas contextualizados em sala de aula de Matemática. Rodrigues (2010) versa acerca da política curricular cabo-verdiana, destacando a constituição da língua crioula como enunciação cultural.

\section{Análise sobre os artigos}

Os 38 artigos da categoria Currículo foram separados em 5 subcategorias: 1) O ensino da História e Cultura Africana e Afro-Brasileira; 2) Reflexões sobre as Relações Étnico-Raciais no Currículo; 3) África e Diáspora; 4) Educação e Relação Étnico-Raciais: o Estado do Conhecimento e 5) Relações Étnico-Raciais e Representação.

\section{O ensino da História e Cultura Africana e Afro-Brasileira}

Os artigos reunidos nesta subcategoria refletem acerca das possibilidades e dos desafios da inclusão da História e Cultura Africana e Afro-Brasileira a partir da implementação da Lei no 10.639/2003 em diferentes áreas do conhecimento: História, Geografia, Língua Portuguesa, Artes, Matemática e Educação Física. A maior parte dos trabalhos apresenta resultados de pesquisas e de práticas curriculares realizadas nas instituições da educação básica, mas também há experiências que discutem sobre os resultados de ações desenvolvidas no ensino superior. Os trabalhos são os seguintes: Baches (2008); Caetano (2012); Costa (2011); Cunha Júnior (2013); Farina (2011), Ferreira e Silva (2013); Felipe e Teruya (2010); Gonçalves, Antunes (2008), Júnior (2010); Martins, Varani e Aparecida (2013); Oliveira e Machado (2010); Ponciano, Gebran e Luvizotto (2011); Rodrigues (2009); Silva (2011); Silva, Pereira (2014); Sodré (2009); Teixeira Jr. (2013) e Uberti (2012). 
Os artigos desta subcategoria apontam possibilidades de ações e sugestões nas diferentes áreas do conhecimento para o ensino da História e Cultura Africana e Afro-Brasileira: “[...] a literatura de temática africana proporciona, ao aluno, maior contato com a diversidade cultural e étnica, levando-o a conhecer novas formas de relacionamento social e manifestação cultural. [...]" Entretanto, as produções apontam que estas práticas são permeadas pelo mito da democracia racial e pela ideologia do branqueamento. E que há um longo caminho a ser percorrido para que sejam realizadas práticas curriculares interculturais.

Apesar do novo marco legal e normativo, dada a novidade pedagógica em pauta, é de se reconhecer que há ainda muitas dificuldades para que as instituições educacionais realizem com propriedade o ensino da História e Cultura Africana e Afro-Brasileira, como aponta o artigo de Caetano (2012, p. 118-119) O autor conclui que a Lei enfrenta obstáculos para a sua implementação e que "para o samba ser aproveitado nas aulas de geografia constituindo uma forma de implementação da referida lei e de suas diretrizes tornam imperiosas discussões e mudanças sobre/no currículo escolar" (CAETANO, 2012, p. 128).

\section{Reflexões acerca das Relações Étnico-Raciais no Currículo}

Esta subcategoria integra os artigos que refletem sobre as Relações Étnico-Raciais no Currículo. Os artigos são os seguintes: Akkari e Santiago (2010), Apple (2006); Gabriel e Costa (2010); Gomes (2012); Pontes, Macedo (2011), Silva (2004), Silva (2007), Silva e Araújo (2011); Onofre (2008); Restrepo, Rojas (2012); Santana, J. Santana, M. e Moreira (2013), Santos e Coelho (2014).

É recorrente a abordagem de que o arcabouço legal a partir de 2003 tem tensionado o currículo hegemônico e as relações étnico-raciais nas instituições educacionais, fortemente marcadas pelo racismo, preconceito racial e discriminação racial. Há indagações contundentes aos currículos hegemônicos e aos processos de ensino que continuam silenciando e/ou omitindo a História e Cultura Africana e Afro-Brasileira. A alteração dessa situação impõe o acesso a conhecimentos efetivos sobre a temática.

Para além da mera vontade, a desconstrução das imagens negativas do Continente Africano faz-se com estudo, conhecimento e compreensão atentos à sua personalidade histórica, geográfica e cultural específica [...] Evidentemente, com esse regime de estereotipias o Continente Africano mais do que qualquer outro foi desqualificado pelo pensamento ocidental com imagens particularmente negativas e excludentes. Várias dessas estereotipias encontram-se evidentes a partir de primados geográficos explicitados nos mapas, livros didáticos, entre outros que sumamente 
referendam discursos construídos sobre esse Continente. (SANTOS, COELHO, 2014, p. 134).

Nesses trabalhos, o currículo é entendido como articulado às relações históricas, sociais, políticas e econômicas e como espaço de disputa em torno do que é considerado valioso a ser ensinado. Para que a implementação da Lei $\mathrm{n}^{\circ} 10.639 / 2003$ seja efetiva, é necessária que ocorra a descolonização dos currículos, o que implica trazer à tona os conflitos, as tensões e as contradições:

[...] É nesse contexto que se encontra a demanda curricular de introdução obrigatória do ensino de História da África e das culturas afro-brasileiras nas escolas da educação básica. Ela exige mudança de práticas e descolonização dos currículos da educação básica e superior em relação à África e aos afro-brasileiros. Mudanças de representação e de práticas. Exige questionamento dos lugares de poder. Indaga a relação entre direitos e privilégios arraigada em nossa cultura política e educacional, em nossas escolas e na própria universidade. (GOMES, 2012, p. 100).

\section{África e Diáspora}

Esta subcategoria agrega os artigos que refletem sobre práticas curriculares no Continente Africano e na Diáspora, destacando aspectos acerca dos desafios e das possibilidades da inserção nos currículos da História Africana e da Diáspora. Os trabalhos são os seguintes: King (2012); Lufwankenda (2009), Ndimande (2011); Restrepo e Rojas (2012).

$\mathrm{O}$ artigo de King focou a sua experiência e práxis comunitária nos contextos dos Estados Unidos e do rico legado do Mali. A autora contrapõe o pensamento e a teorização do modelo de Déficit Cultural acerca da linguagem e da cultura das crianças negras. Interroga o discurso da inferioridade negra e destaca a importância dos(as) estudantes desenvolverem uma consciência crítica, contribuindo para a sua excelência cultural e acadêmica.

Este entendimento de excelência educacional é apoiado por pesquisas que demonstram: apresentar a estudantes negros um currículo veraz lhes permite desenvolver identidades positivas quanto a si mesmos e a seus grupos, e alcançar uma excelência cultural e acadêmica que não é restrita pelas definições eurocêntricas de realização acadêmica. (KING, 2012, p. 72). 


\section{Educação e Relações Étnico-Raciais: o Estado do Conhecimento}

Esta subcategoria integra 3 artigos que realizam o balanço da produção do conhecimento na área da Educação e Relações Étnico-Raciais. Os trabalhos são os seguintes: Regis (2009); Regis (2011) e Baches (2013)

O artigo de Regis (2011) discutiu resultados de doutorado que sistematizou e analisou os principais temas discutidos em teses e dissertações sobre relações étnico-raciais e currículos escolares, realizadas em programas de pós-graduação stricto sensu em Educação. Foram identificamos 187 estudos sobre relações étnico-raciais e Educação. Entre eles, foram selecionamos os 51 trabalhos que versaram sobre relações étnico-raciais nos currículos. Foram recuperamos 29 estudos, que foram lidos e analisados utilizando os referenciais da análise de conteúdo, por meio da análise categorial (BARDIN, 2008). Como resultado, as pesquisas foram agrupadas em 4 categorias: a) o negro nos livros didáticos; b) relações étnico-raciais no currículo em ação; c) estereótipos, preconceito racial e discriminação racial no cotidiano escolar e d) o ensino da história e cultura dos africanos e dos negros brasileiros nos currículos escolares. $\mathrm{O}$ artigo refletiu sobre a última categoria, discutindo os desafios para a inclusão da História e Cultura Africana e Afro-Brasileira no currículo. Segundo a autora, a produção discente analisada destaca que o ensino da temática ocorre de maneira pontual, por meio de práticas isoladas e à margem do currículo hegemônico.

Em outro artigo, Regis (2009) apresentou o resultado da análise de treze teses e dissertações sobre o tema Educação Não-Escolar de Adultos e Relações Étnico-Raciais, desenvolvidas em programas de pós-graduação em Educação e Ciências Sociais, entre os anos 1999 e 2006. A produção discente examinada revela que as práticas educativas - realizadas pelas entidades do movimento negro, organizações da sociedade civil, núcleos culturais da população negra e por meio de práticas religiosas - são importantes para problematizar a exclusão a que está submetida a população negra na sociedade brasileira. Outro aspecto comum a essas pesquisas diz respeito às críticas direcionadas às instituições educacionais, que por meio de seus currículos têm omitido e/ou distorcido a História e Cultura Africana e Afro-Brasileira. Os trabalhos também apontam proposições e oferecem elementos para alterá-los.

\section{Relações Étnico-Raciais e Representação}

Esta subcategoria integra dois artigos que versam sobre as representações e as relações étnico-raciais: Silva e Coelho (2010) e Santos e Coelho (2012). Santos e Coelho (2012) analisam as representações sociais de professores(as) sobre a Lei ${ }^{\circ}$ 10.639/2003 e as Diretrizes Curriculares Nacionais para a Educação das Relações 
Étnico-Raciais e para o Ensino da História e Cultura Africana e Afro-Brasileira no currículo do ensino fundamental. As autoras utilizaram como instrumentos de coleta de dados os documentos oficiais, questionário e grupo focal. No Grupo Focal foi realizada uma dinâmica de interlocução com base nas seguintes questões: a) $\mathrm{O}$ que você entende por diversidade cultural?;b) Qual o conhecimento que você tem acerca dos marcos legais no tocante à Diversidade Cultural?; f) De que maneira você trabalha o estudo da História da África e dos Africanos e a cultura negra brasileira? Para o entendimento do ensino da História da África e dos africanos e da cultura negra brasileira na representatividade de professores, foi utilizado como critério o conhecimento de professores sobre da Lei Federal 10.639/2003, por meio de questionário com as perguntas: Qual o seu conhecimento sobre a Lei $\mathrm{n}^{\mathrm{o}} 10.639 / 2003$ ? Você trabalha na sala de aula? Em caso positivo, de que forma?

Os professores apresentaram como marco legal a LDB, alguns se sentem intimados, outros desconhecem a Lei Federal 10.639/2003 e outros se sentem obrigados a trabalharem o ensino de história e cultura afro-brasileira no currículo escolar. (SANTOS, COELHO, 2012, p. 46).

\section{Caminhos abertos para a pesquisa}

Os resultados da análise das teses e dissertações da Categoria Currículo evidenciaram algumas questões que são abordadas na produção acadêmica por meio das 5 subcategorias: os desafios e as possibilidades do ensino da História e Cultura Africana e Afro-Brasileira nos currículos escolares de diferentes áreas do conhecimento; as práticas curriculares desenvolvidas no cotidiano das instituições educacionais, problematizando a incompatibilidade entre o estabelecido no arcabouço legal e o que ocorre no currículo na ação; a discussão sobre o modo como ocorrem as relações étnico-raciais nas escolas; e os desafios da inserção da diversidade étnico-racial no currículo em uma escola homogeneizadora e estruturada com base na perspectiva do universalismo abstrato.

A leitura e a análise dos artigos demonstraram algumas recorrências nos temas abordados: a crítica ao currículo eurocêntrico unifica a produção. Uma parte significativa dos artigos refletem acerca das possibilidades e dos desafios da inclusão da História e Cultura Africana e Afro-Brasileira a partir da implementação da Lei $n^{\circ} 10.639 / 2003$. Outra questão bastante discutida nos trabalhos foi a problematização do currículo, que tem silenciado acerca da História e Cultura Africana e Afro-Brasileira, e proposições para o ensino da 
temática. Também foram abordados o currículo em países africanos e da diáspora; artigos que versam sobre a Educação e Relações Étnico-Raciais: o Estado do Conhecimento e sobre representação. A problematização sobre o ensino do tema realizada pela produção examinada contribui para a indagação das práticas curriculares hegemônicas e oferecem importantes subsídios para a construção de práticas curriculares que contemplem a diversidade étnico-racial do Brasil.

Entretanto, há outras possibilidades de pesquisa acerca do tema: como tem sido a inserção da temática nos projetos político-pedagógicos e quais os possíveis impactos na prática curricular? Qual é a participação da comunidade e dos movimentos negro na efetivação dos currículos realizados cotidianamente nas instituições educacionais? Como as pesquisas com outros sujeitos que atuam no cotidiano escolar podem colaborar para a problematização de como ocorre o ensino da História e Cultura Africana e Afro-Brasileira? Qual é a atuação das secretarias municipais e estaduais de ensino para a institucionalização da Lei $\mathrm{n}^{\mathrm{o}} 10.639 / 2003$ ? Como as instituições de ensino superior nas diferentes áreas do conhecimento estão inserindo, ou não, nos seus currículos a temática? Quais os impactos da Lei $\mathrm{n}^{\circ}$ 10.639/2003 nas instituições particulares laicas e nas confessionais? Como está a regulamentação nos documentos normativos e de planejamento dos estabelecimentos de ensino acerca da Lei $n^{0} 10.639 / 2003$; a existência ou não de grupos de trabalhos sobre a educação das relações étnico-raciais nos sistemas de ensino; quais são as condições financeiras para execução de projetos sobre a temática e mecanismos de avaliação da efetivação da Lei; se há e quais são as ações conjuntas entre os diferentes entes federados para a efetivação do arcabouço legal acerca da História e Cultura Africana e Afro-Brasileira; se e como ocorre a articulação com os estabelecimentos de ensino superior, centros de pesquisa, NEABs e grupos correlatos, escolas, comunidade e movimentos sociais para a configuração do currículo nos diferentes níveis, etapas e modalidades de ensino; pesquisas que contemplem o ensino superior, a educação infantil, a educação de jovens e adultos e a educação especial; realização de investigações em áreas do conhecimento como Química, Física, Filosofia, Sociologia e a produção de pesquisas que reflitam sobre as relações étnico-raciais em interface com as relações de gênero e de orientação sexual.

\section{Recomendações para a implementação da Lei $\mathbf{n}^{0}$ 10.639/03}

A partir de 2003, no Brasil um arcabouço legal marca uma mudança histórica decisiva para a adoção de políticas antirracistas, sobretudo na área 
educacional, e para a superação as desigualdades étnico-raciais, uma das manifestações mais contundentes das disparidades no país. Essa legislação teve o mérito de situar no cerne da discussão curricular a imediata inserção da História e Cultura Africana e Afro-Brasileira. A Lei n ${ }^{\circ}$ 10.639/2003 está possibilitando o tensionamento do currículo hegemônico e impondo questionamentos aos sistemas de ensino e às instituições educacionais. Essa lei quebra o provincialismo e abre possibilidade de cruzamento intercultural no currículo. Para que se efetive a inserção da História e Cultura Africanas e Afro-Brasileira no currículo é imprescindível a mudança de perspectiva dos currículos que têm se restringido a pautar a História Mundial valendo-se da perspectiva e dos marcos do continente europeu.

É evidente que, para mudar mentalidades, imaginários, valores, formas de pensar, condutas preconceituosas e a forma estereotipada com que a História e Cultura Africana e Afro-Brasileira é ensinada nas instituições educacionais, as alterações curriculares precisam estar correlacionadas a outras políticas ainda mais abrangentes e includentes. Daí a necessidade de comprometimento das estruturas do Estado, das estruturas do poder e da articulação das políticas educacionais com outras políticas públicas que favoreçam a étnico-racial brasileira.

Apesar de todo o avanço nas políticas públicas, na legislação que determina a obrigatoriedade de se estudar a História e Cultura Africana e Afro-Brasileira, ainda há muitas dificuldades a serem superadas para que as instituições educacionais realizem com propriedade o ensino da temática para propiciar práticas curriculares interculturais. A produção acadêmica analisada na Categoria Currículo oferece importantes recomendações para a implementação da Lei ${ }^{\circ}$ 10.639/2003:

- formação inicial e formação continuada dos(as) professores(as) e dos(as) gestores(as) para o ensino da História e Cultura Africana e Afro-Brasileira;

- produção e socialização de materiais didáticos sobre a temática;

- inclusão de disciplinas e conteúdos sobre a educação das relações étnico-raciais e sobre a História e Cultura Africana e Afro-Brasileira nos cursos de graduação e de pós-graduação das diferentes áreas do conhecimento nas Instituições de Ensino Superior;

- desenvolvimento de ações conjuntas entre os sistemas de ensino; universidades; Núcleos de Estudos Afro-Brasileiros (NEABS) e grupos correlatos; movimento negro e comunidade para a realização de uma prática educativa intercultural, que estejam articuladas à outras políticas públicas que contemplem a diversidade étnico-racial brasileira;

- aumento e socialização das pesquisas sobre o tema; 
- inserção da História e Cultura Africana e Afro-Brasileira nos Projetos Políticos-Pedagógicos das instituições educacionais, que sejam construídos coletivamente;

- ampliação e consolidação dos diálogos entre as universidades brasileiras e as africanas para a produção e a troca de conhecimentos sobre o tema, com o desenvolvimento de pesquisas conjuntas que ofereçam novos fundamentos epistemológicos para possibilitar a implementação da Lei $\mathrm{n}^{\circ} 10.639 / 2003$ e que permitam superar visões estereotipadas e preconceituosas acerca do Continente Africano;

- criação e/ou ampliação de grupos de trabalhos nas secretarias estaduais e municipais de educação para o desenvolvimento e a avaliação de ações acerca da Educação para as Relações Étnico-Raciais e para o ensino da História e Cultura Africana e Afro-Brasileira;

- enfrentamento das situações de racismo, de preconceito racial e de discriminação racial no cotidiano escolar em todos os níveis, etapas e modalidades de ensino;

- maior aporte de recursos financeiros para as políticas educacionais e, particularmente, para a efetivação de ações para a implementação da Lei $\mathrm{n}^{\circ} 10.639 / 2003$;

- estrutura física adequada e melhores condições de trabalho nas instituições educacionais;

- realização de práticas curriculares interdisciplinaridades para possibilitar a integração dos conteúdos acerca da História e Cultura Africana e Afro-Brasileira.

\section{REFERÊNCIAS}

SACRISTÁN, J. G. O currículo: os conteúdos do ensino ou uma análise da prática? In: SACRISTÁN, J. G.; GÓMEZ, A. I. P. Compreender e transformar o ensino. 4. ed. Porto Alegre: Artmed, 1998. p. 119-148.

SACRISTÁN, J. G.; GÓMEZ. A. I. P. O que significa o currículo? In: Saberes e incertezas sobre o currículo. SACRISTÁN, J. G. Porto Alegre: Penso, 2013. p. 16-35.

\section{Teses e dissertações analisadas}

ALVES, R. de C. D. A africanidade no currículo: a lei federal 10.639/03 e as práticas curriculares de escolas públicas de Sabará. 2013. Dissertação (Programa de Pós-Graduação 
em Educação, Subárea: Educação escolar e profissão docente) - Pontifícia Universidade Católica de Minas Gerais, 2013. Disponível em: <http://www.biblioteca.pucminas.br/ teses/Educacao_AlvesRC_1.pdf>.Acesso em: 14 set. 2015.

ALVES, T. de A. Herdanças de corpos brincantes: os saberes da corporeidade/africanidade em danças afro-brasileiras. 2003. Tese (Programa de pós-graduação em Educação) - Universidade Federal do Rio Grande do Norte, 2003. Disponível em: <http://www. biblioteca-acaoeducativa.org.br/dspace/bitstream/123456789/370/1/Teodora_Araujo_Alves.pdf>. Acesso em: 4 out. 2015.

AMORIM, R. M. de. As práticas curriculares cotidianas: um estudo da educação das relações étnico-raciais em escola da rede municipal de ensino do Recife. 2011. Tese (Programa de Pós-graduação em Educação) - Universidade Federal de Pernambuco, 2011. Disponível em: <http://repositorio.ufpe.br/bitstream/handle/123456789/4159/ arquivo5755_1.pdf?sequence=1\&isAllowed=y>. Acesso em: 20 jul. 2015.

BARROS, A. R. de. Trilhas e partilhas na prática pedagógica de dança afro-brasileira. 2011. Dissertação (Programa de Pós-Graduação em Educação, subárea: Formação de Professores e Prática Pedagógica) - Universidade Federal de Pernambuco, 2011.

BENTO, C. C. Jogos de origem ou descendência indígena e africana na educação física escolar: educação para e nas relações étnico-raciais. 2012. Dissertação (Programa de Pós-Graduação em Educação, subárea: Práticas Sociais e Processos Educativos) - Universidade Federal de São Carlos, 2012. Disponível em: <http://www.bdtd.ufscar.br/htdocs/ tedeSimplificado/tde_busca/arquivo.php?codArquivo=5548>. Acesso em: 21 nov. 2015.

BRAÇO, A. D. Educação pelos ritos de iniciação: contribuição da tradição cultural ma-sena ao currículo formal das escolas de Moçambique. 2008. Dissertação (Programa de Pós-Graduação em Educação, Subárea: currículo) - Pontifícia Universidade Católica de São Paulo, 2008. Disponível em: <http://www.sapientia.pucsp.br/tde_busca/arquivo. php? codArquivo=8185>. Acesso em: 18 ago. 2015.

CAETANO, A. O samba no ensino da geografia: reflexões para a implementação da lei n ${ }^{\circ} 10639 / 03$ na perspectiva do multiculturalismo. 2012. Dissertação (Programa de Pós-Graduação em Educação, subárea: Práticas Educativas, Linguagens e Tecnologia) - Universidade Federal do Estado do Rio de Janeiro, 2012. Disponível em: <https:// docs.google.com/file/d/0B-sE2Ar37CoNd2NDNmJORE45SWc/edit>. Acesso em: 21 nov. 2015.

CORREIA, R. A. L. Akpalô: compondo linguagens africano-brasileiras para o currículo da educação infantil no município de Santo Amaro de Ipitanga. 2014. Dissertação (Programa de Pós-Graduação em Educação) - Universidade do Estado da Bahia, 2014. Disponível em: <http://www.cdi.uneb.br/pdfs/educacao/2014/1109141411.pdf>. Acesso em: 30 dez. 2015.

COSTA, C. S. da. Educação para as relações étnico-raciais: história e cultura afro-brasileira e africana no currículo do ensino médio. 2011. Tese (Programa de Pós-Graduação em Educação, subárea: Classes sociais, gênero, raça e educação) - Universidade Federal 
Fluminense, 2011. Disponível em: $<$ https://www.google.com.br/url?sa=t\&rct=j\&q=\&esrc $=$ s\&source $=$ web \&cd $=2 \&$ cad $=$ rja \&uact $=8 \&$ ved $=0$ CCIQFjABahUKEwjurLaasvLIAhWB CpAKHealCGM\&url=http\%3A\%2F\%2Fwww.ppg-educacao.uff.br\%2Fnovo\%2Findex. php\%2Fcomponent $\% 2$ Fk2\%2Fitem\%2Fdownload\%2F52_8ee28e92768655c127874c d525faa9db\&usg=AFQjCNF_83WZyFMMl-mUDwyUKHKr13ytdA\&sig2=nDZbt7k Zw-qwHSNv9tnkbg\&bvm=bv.106379543,d.Y2I>. Acesso em: $1^{\circ}$ dez. 2015.

COSTA, L. H. da. Identidade e multiculturalismo: a construção de identidades raciais em uma escola de ensino fundamental. 2011. Dissertação (Programa de Pós-Graduação em Educação, subárea: Instituições Educacionais e suas Práticas Pedagógicas) - Universidade Católica de Petrópolis, 2011.

COSTA, W. da. Currículo e produção da diferença: "negro" e "não-negro" na sala de aula de história. 2012. Tese (Programa de pós-graduação em Educação, subárea: Currículo e Linguagem) - Universidade Federal do Rio de Janeiro, 2012. Disponível em: $<$ http:// www.educacao.ufrj.br/ppge/teses/Tese_Warley_Final.pdf $>$. Acesso em: $1^{\circ}$ dez. 2015.

CROCETTA, R. R. J. As relações étnico-raciais nos currículos dos cursos de licenciatura em educação física das instituições de ensino superior do sistema acafe. 2014. Dissertação (Programa de Pós-Graduação em Educação) - Universidade do Sul de Santa Catarina, 2014. Disponível em: < http://aplicacoes.unisul.br/pergamum/pdf/109800_Renata.pdf > Acesso em: 17 out. 2016.

CRUZ, E. M. R. Percepções das crianças sobre currículo e relações étnico-raciais na escola: desafios, incertezas e possibilidades. 2008. Dissertação (Programa de Pós-Graduação em Educação, subárea: Processos de Ensino e Aprendizagem) - Universidade Federal de São Carlos, 2008. Disponível em: <http://www.bdtd.ufscar.br/htdocs/ tedeSimplificado/tde_busca/arquivo.php?codArquivo=2175>. Acesso em: 26 set. 2015.

DUARTE, A. D. B. Histórias em quadrinhos sobre culturas afrodescendentes na educação. 2006. Dissertação (Programa de Pós-Graduação em Educação) - Universidade do Estado do Rio de Janeiro, 2006. Disponível em: <http://www.proped.pro.br/teses/ teses_pdf/2004_1-46-ME.pdf>. Acesso em: 18 ago. 2015.

DULI, J. L. B. Estudo sobre as estratégias utilizadas pelos alunos na resolução de problemas contextualizados em Cabinda/Angola. 2014. Dissertação (Programa de Pós-Graduação em Educação, subárea: Educação Matemática) - Universidade Federal de Minas Gerais, 2014. Disponível em: < https:/www.bibliotecadigital.ufmg.br/dspace/ bitstream/handle/1843/BUOS-9PMK78/1elo_disserta_o_vers_o_final_2014_cat.. pdf? sequence $=1>$. Acesso em: 5 set. 2015.

FERNANDES, L. de O. O jongo, a ancestralidade africana e a educação escolar: um estudo sobre tensões, negociações e possibilidades. 2012. Dissertação (Programa de Pós-Graduação em Educação, subárea: Educação e Diversidades Étnico-Raciais) - Universidade Federal Rural do Rio de Janeiro, 2012.

FERNANDES, R. B. G. No movimento do currículo: a diversidade étnico-racial em escolas na rede municipal de ensino de Florianópolis (2010-2011). 2011. Dissertação 
(Programa de Pós-Graduação em Educação, subárea: Ensino e Formação de Educadores) - Universidade Federal de Santa Catarina, 2011. Disponível em: $<$ https://repositorio. ufsc.br/bitstream/handle/123456789/95395/301418.pdf? sequence=1\&isAllowed=y $>$. Acesso em: 29 set. 2015.

GONCALVES, A. M. T. Práticas e aprendizagens em jogo: um estudo comparado entre a capoeira angola-MG e a capoeira regional-BA, em diálogo com os saberes escolares. 2012. Dissertação (Programa de Pós-Graduação em Educação, subárea: Educação escolar: políticas e práticas curriculares, cotidiano e cultura) - Pontifícia Universidade Católica de Minas Gerais, 2012. Disponível em: <http://www.biblioteca.pucminas.br/ teses/Educacao_GoncalvesAMT_1.pdf>.Acesso em: 31 out. 2015.

KOHL, H. G. Gingado na prática pedagógica escolar: expressões lúdicas no quefazer da educação física. 2007. Tese (Programa de Pós-Graduação em Educação, subárea: Teoria e história da Educação) - Universidade Federal de Pernambuco, 2007. Disponível em: <http://repositorio.ufpe.br/handle/123456789/13003?show=full $>$. Acesso em: 15 jan. 2016.

MACÊDO, D. de J. S. O currículo escolar e a construção da identidade étnico-racial da criança e do adolescente quilombola: um olhar reflexivo sobre a autoestima. 2008. Dissertação (Programa de Pós-Graduação em Educação) - Universidade do Estado da Bahia, 2008. Disponível em: <http://www.cdi.uneb.br/pdfs/educacao/2008/dinalva_de_jesus_santana_macedo.pdf $>$. Acesso em: 22 mar. 2016.

MACHADO, A. F. Ancestralidade e encantamento como inspirações formativas: filosofia africana mediando a história e cultura africana e afro-brasileira. 2014. Dissertação (Programa de Pós-Graduação em Educação, subárea: Currículo e (In) formação) - Universidade Federal da Bahia, 2014. Disponível em: <https://repositorio.ufba.br/ri/bitstream/ri/16155/1/Ancestralidade $\% 20 \mathrm{e} \% 20$ Encantamento $\% 20$ como $\% 20$ inspira $\%$ C3\%A7\%C3\%B5es $\% 20$ formativas $\% 20-\% 20$ filosofia $\% 20$ africana $\% 20$ mediando $\% 20$ a $\% 20$ HCAA. $\% 20$ Adilb $\%$ C3\%AAniaMachado $\% 20-\% 20$ Disserta\%C3\%A7\%C3\%A3o.pdf>. Acesso em: 22 mar. 2016.

MACHADO, I. C. S. Professoras negras na UERJ e cotidianos curriculares, a partir dos primeiros tempos do acervo fotográfico J. Vitalino. 2011. Dissertação (Programa de Pós-Graduação em Educação, subárea: Cotidianos, Redes Educativas e Processos Culturais) - Universidade do Estado do Rio de Janeiro, 2011. Disponível em: <http:// cev.org.br/arquivo/biblioteca/4024144.pdf>. Acesso em: 31 out. 2015.

MACHADO, S. A. da M. Saberes e fazeres na capoeira angola: a autonomia no jogo de muleekes. 2012. Dissertação (Programa de Pós-Graduação em Educação, subárea: Linha Educação, Cultura Corporal e Lazer) - Universidade Federal da Bahia, 2012. Disponível em: <https://repositorio.ufba.br/ri/bitstream/ri/13025/1/Sara\%20Abreu\%20 da\%20M.\%20Machado.pdf>. Acesso em: 22 mar. 2016.

MARANHÃO, F. Jogos africanos e afro-brasileiros nas aulas de educação física: processos educativos das relações étnico-raciais. 2009. Dissertação (Programa de Pós-Graduação 
em Educação) - Universidade Federal de São Carlos, 2009. Disponível em: < http://www. bdtd.ufscar.br/htdocs/tedeSimplificado/tde_busca/arquivo.php?codArquivo=2827>. Acesso em: 3 abr. 2016.

MARQUES, E. P. de S. A pluralidade cultural e a proposta pedagógica na escola? Um estudo comparativo entre as propostas pedagógicas de uma escola de periferia e uma escola de remanescentes de quilombos. 2004. Dissertação (Programa de Pós-Graduação em Educação, subárea: Educação Escolar e Formação de Professores) - Universidade Católica de Brasília, 2004. Disponível em: <http://site.ucdb.br/public/md-dissertacoes/7793-a-pluralidade-cultural-e-a-proposta-pedagogica-na-escola-um-estudo-comparativo-entre-as-propostas-pedagogicas-de-uma-escola-de-periferia-e-uma-escola-de-remanescentes-de-quilombos.pdf>. Acesso em: 29 set. 2015.

MATTOS, I. G de. É pra descer quebrando: o pagode e suas performances para a educação das relações étnico-raciais no currículo escolar. 2013. Tese (Programa de Pós-Graduação em Educação) - Universidade do Estado da Bahia, 2013. Disponível em: <http://www. cdi.uneb.br/pdfs/teses/2013/2508141339.pdf>. Acesso em: 22 maio 2016.

MELLO, R. M. de. É a cor da pele que faz a pessoa ser discriminada: narrativas sobre o negro e a discriminação racial produzidas em uma experiência pedagógica de educação matemática. 2006. Dissertação (Programa de Pós-Graduação em Educação) - Universidade do Vale do Rio do Sinos, 2006. Disponível em: <http://www.repositorio.jesuita.org.br/bitstream/handle/UNISINOS/1896/e\%20a\%20cor\%20da\%20pele. pdf? sequence $=1 \&$ is Allowed=y $>$. Acesso em: 30 nov. 2016.

MENDONÇA, A. P. F. de. Pedagogias antirracistas: tensões e possibilidades de caminhos em construção. 2011. Dissertação (Programa de Pós-Graduação em Educação, subárea: Formação de Professores e Práticas Educativas) - Universidade Federal De Viçosa, 2011. Disponível em: <http://alexandria.cpd.ufv.br:8000/teses/educacao/2011/238903f.pdf>. Acesso em: 30 nov. 2016.

MOTA, B. M. C. da S. Ensino de história e cultura afro-brasileira: uma análise do caderno do professor de história do ensino médio público paulista. 2014. Dissertação (Programa de Pós-Graduação em Educação, subárea: Políticas Educacionais, Gestão de Sistemas e Organizações, Trabalho e Movimentos Sociais). Universidade Estadual Paulista "Júlio De Mesquita Filho". 2014. Disponível em: $<$ http://www.marilia.unesp. br/Home/Pos-Graduacao/Educacao/Dissertacoes/mota_bmcs_me_mar.pdf $>$. Acesso em: 25 mar. 2016.

NETO, L. G. Alunos africanos de Guiné Bissau, São Tomé Príncipe e Cabo Verde na Universidade Federal do Ceará-UFC: relações culturais, alimentares e curriculares. 2012. Dissertação (Programa de Pós-Graduação em Educação, subárea: Educação, Currículo e Ensino) - Universidade Federal do Rio de Janeiro, 2012.

NICOLIN, J. S. Artebagaço odeart ecos que entoam a mata africano-brasileira do cabula. 2007. Dissertação (Programa de Pós-Graduação em Educação) - Universidade do Estado da Bahia, 2007. Disponível em: <http://www.cdi.uneb.br/pdfs/educacao/2007/ janice_de_sena_nicolin.pdf $>$. Acesso em: $1^{\circ}$ fev. 2016. 
NOGUEIRA, S. G. Processos educativos da capoeira angola e construção do pertencimento étnico-racial. 2007. Dissertação (Programa de Pós-Graduação em Educação) - Universidade Federal de São Carlos, 2007.

NOVAES, Í. F. de. Resistência e proliferação: conversas com imagens de África(s) e professores de geografia. 2014. Tese (Programa de Pós-Graduação em Educação, subárea: Educação, Conhecimento, Linguagem e Arte) - Universidade Estadual de Campinas, 2014. Disponível em: <http://www.bibliotecadigital.unicamp.br/document/?code=000 934526\&opt=1>. Acesso em: 31 out. 2015.

OLIVEIRA, E. de. Relações étnico-raciais e de gênero e o discurso da sala de aula de português: uma abordagem etnográfica interacional. 2008. Tese (Programa de Pós-Graduação em Educação) - Universidade Federal de Minas Gerais, 2008. Disponível em: <http:// www.bibliotecadigital.ufmg.br/dspace/bitstream/handle/1843/CPSA-7PMH85/tese_elania_pdf_vers_o_final_p_s_defesa_24_nov._08.pdf? sequence=1>.Acesso em: 3 fev. 2016 .

OLIVEIRA, L. M. de. O ensino da história e cultura afro-brasileira e a educação física: um estudo sobre o currículo vivido em Santo André. 2012. Dissertação (Programa de Pós-Graduação em Educação, subárea: currículo) - Pontifícia Universidade Católica de São Paulo, 2012. Disponível em: <http://www.sapientia.pucsp.br/tde_busca/arquivo. php?codArquivo=13917>. Acesso em: 15 jan. 2016.

OLIVEIRA, L. B. de S. Cultura afrocearense: um estudo sobre africanidades, educação e currículo numa escola pública de fortaleza. 2011. Dissertação (Programa de Pós-Graduação em Educação, subárea: Movimentos Sociais, Educação Popular e Escola) - Universidade Federal do Ceará, 2011. Disponível em: <http://www.repositorio.ufc.br/ bitstream/riufc/3399/1/2011_Dis_LBSOliveira.pdf>. Acesso em: 24 jul. 2016.

PEREIRA, M. G. História da África, uma disciplina em construção. 2012. Tese (Programa de Pós-Graduação em Educação, subárea: História, Política, Sociedade) - Pontifícia Universidade Católica de São Paulo, 2012. Disponível em: $<$ http://www.sapientia.pucsp. br/tde_busca/arquivo.php?codArquivo=14763>. Acesso em: 22 mar. 2016.

PEREIRA, M. Racismo na educação: estratégia do estado \& uma possibilidade de superação. 2009. Dissertação (Programa de Pós-Graduação em Educação, Subárea: currículo) - Pontifícia Universidade Católica de São Paulo, 2009. Disponível em: <http://www. sapientia.pucsp.br/tde_busca/arquivo.php?codArquivo=9171>. Acesso em: 22 mai. 2016.

PEREIRA, R. P. O jogo africano mancala e o ensino de matemática em face da lei 10.639/03. 2011. Dissertação (Programa de Pós-Graduação em Educação, subárea: Movimentos Sociais, Educação Popular e Escola) - Universidade Federal do Ceará, 2011. Disponível em: $<$ http://www.repositorio.ufc.br/bitstream/riufc/3223/1/2011_Dis_RPPEREIRA.pdf $>$. Acesso em: 24 jul. 2016.

PEREIRA, S. B. Identidade e diferença étnico-racial em currículos e programas: afirmação ou silenciamento? 2006. Dissertação (Programa de pós-graduação em Educação). Universidade Federal do Maranhão, 2006. Disponível em: <http://www.tedebc.ufma.br/ tde_busca/arquivo.php?codArquivo=10>. Acesso em: 13 ago. 2016. 
PEREIRA, S. B. O currículo como percurso de reconhecimento da identidade negra: políticas e práticas curriculares no Instituto Federal de Educação, Ciência e Tecnologia do Maranhão (IFMA); Campus Monte Castelo. 2013. Tese (Programa de Pós-Graduação em Educação, subárea: Currículo) - Pontifícia Universidade Católica de São Paulo, 2013. Disponível em: <http://www.sapientia.pucsp.br/tde_busca/arquivo. php? codArquivo=16642>. Acesso em: 13 ago. 2016.

PINHEIRO, C. G. Narrativas de educação e resistência: a prática popular griô. 2013. Dissertação (Programa de Pós-Graduação em Educação) - Universidade Federal de Pelotas, 2013. Disponível em: <http://guaiaca.ufpel.edu.br/bitstream/123456789/1654/1/ Cristiano\%20Guedes\%20Pinheiro_Dissertacao.pdf>. Acesso em: 24 jul. 2016.

PONCIANO, D. D. História e cultura afro-brasileiras no currículo de história do $6^{\circ}$ ao $9^{\circ}$ anos da rede oficial do estado de Sáo Paulo. 2011. Dissertação (Programa de Pós-Graduação em Educação, subárea: Formação e Prática Pedagógica do Profissional Docente) - Universidade do Oeste Paulista, 2011. Disponível em: <http://tede.unoeste. br/tede/tde_busca/arquivo.php?codArquivo=240>. Acesso em: 20 ago. 2016.

PONTES, C. M. da S. Política curricular, enunciação da diferença e demandas raciais: analisando as diretrizes curriculares nacionais para a educação das relações étnico-raciais e para o ensino de história e cultura afro-brasileira e africana. 2000. Dissertação (Programa de Pós-Graduação em Educação) - Universidade do Estado do Rio de Janeiro, 2000. Disponível em: <http://www.proped.pro.br/teses/teses_pdf/2007_1-244-ME.pdf>. Acesso em: 30 dez. 2015.

RAMOS, S. C. Representações e ensino de história: imagens de alunos do ensino médio sobre a escravidão negra no brasil. 2009. Dissertação (Programa de Pós-Graduação em Educação, subárea: Educação Escolar: Instituições, Sujeitos e Currículos) - Universidade Federal de Minas Gerais, 2009. Disponível em: <http://www.bibliotecadigital.ufmg.br/ dspace/bitstream/handle/1843/VCSA-7Z8P5H/1000000760.pdf?sequence=1>. Acesso em: 20 ago. 2016.

REGIS, K. E. Relações étnico-raciais e currículos escolares em teses e dissertações produzidas nos programas de pós-graduação stricto sensu em educação - Brasil (19872006). 2009. Tese (Programa de Pós-Graduação em Educação, subárea: Currículo) - Pontifícia Universidade Católica de São Paulo, 2009. Disponível em: <http://www. sapientia.pucsp.br/tde_busca/arquivo.php?codArquivo=9016>. Acesso em: 16 out. 2016.

RODRIGUES, A. A. M. Pensar currículo como um enunciado cultural com foco na língua crioula cabo-verdiana. 2010. Dissertação (Programa de Pós-Graduação em Educação) Universidade do Estado do Rio de Janeiro, 2010. Disponível em: <http://www.proped. pro.br/teses/teses_pdf/2008_1-380-ME.pdf $>$. Acesso em: 21 jul. 2015.

SAMPAIO, M. C. de J. O currículo vivido e os repertórios culturais negros nas escolas municipais da Matinha dos Preto-BA: diálogos com a lei 10.639/03. 2013. Dissertação (Programa de Pós-Graduação em Educação) - Universidade Federal de Feira de Santana, 2013. Disponível em: $<$ http://www2.uefs.br/ppge/dissertacao/dissertacao-sampaio-2013. pdf $>$. Acesso em: 17 out. 2016. 
SANTOS, R. M. dos. Agbon: arte, beleza e sabedoria ancestral africana. 2007. Dissertação (Programa de Pós-Graduação em Educação) - Universidade do Estado da Bahia, 2007. Disponível em: $<$ http://www.cdi.uneb.br/pdfs/educacao/2007/ronaldo_martins_dos_santos.pdf $>$. Acesso: em 18 nov. 2016.

SILVA JÚNIOR, F. E. da. Vadiação na escola: dialogando com as contradições do ensino da capoeira. 2010. Dissertação (Programa de Pós-Graduação em Educação) Universidade do Estado da Bahia, 2010. Disponível em: <http://www.cdi.uneb.br/pdfs/ educacao/2011/florisvaldo_evangelista_da_silva_junior.pdf $>$. Acesso em: $1^{\circ}$ dez. 2016.

SILVA, E. de J. da. Um caminho para a África são as sementes: histórias sobre o corpo e os jogos africanos mancala na aprendizagem da educação das relações étnico-raciais. 2010. Dissertação (Programa de Pós-Graduação em Educação, subárea: Educação, sociedade e práxis pedagógica) - Universidade Federal da Bahia, 2010. Disponível em: $<$ https://repositorio.ufba.br/ri/bitstream/ri/10265/1/Dissertacao_Elizabeth\%20de\%20 Jesus.pdf>. Acesso em: 5 set. 2015.

SILVA, F. T. Educação antirracista nos anos iniciais do ensino fundamental no distrito federal: reflexões curriculares. 2013. Dissertação (Programa de Pós-Graduação em Educação, subárea: Profissão docente, currículo e avaliação) - Universidade de Brasília, 2013. Disponível em: <http://repositorio.unb.br/handle/10482/15395>. Acesso em: 18 nov. 2016.

SILVA, M. A. S. da. Prática da capoeira como espaço de formação. 2006. Dissertação (Programa de Pós-Graduação em Educação) - Universidade Federal de Alagoas, 2006. Disponível em: $<$ http://www.repositorio.ufal.br/bitstream/riufal/284/1/Dissertacao_MarcoAntonioSantosdaSilva_2006.pdf >. Acesso em: $1^{\circ}$ dez. 2016.

SILVA, V. L. da. A cultura negra na escola pública: uma perspectiva etnomatemática. 2008. Dissertação (Programa de Pós-Graduação em Educação) - Universidade de São Paulo, 2008. Disponível em: <http://www.teses.usp.br/teses/disponiveis/48/48134/tde12032009-112833/pt-br.php>. Acesso em: 3 mar. 2016.

SILVA, V. L. da. Africanidade, matemática e resistência. 2014. Tese (Programa de Pós-Graduação em Educação) - Universidade de São Paulo, 2014. Disponível em: $<$ http:// www.teses.usp.br/teses/disponiveis/48/48134/tde-09122014-114244/pt-br.php >. Acesso em: 31 dez. 2016.

SOARES, J. N. A introdução da definição de raça nas propostas curriculares brasileiras: a lente da nova lei e os olhos dos alunos. 2009. Dissertação (Programa de Pós-Graduação em Educação) - Universidade São Paulo, 2009. Disponível em: <http://www.teses.usp.br/ teses/disponiveis/48/48134/tde-25092009-090745/pt-br.php>. Acesso em: 15 jan. 2016.

SOARES, J. C. Etno-identificações na escola: atos de currículo e cultura escolar na construção identitária de estudantes negros. 2011. Dissertação (Programa de Pós-Graduação em Educação, subárea: Currículo e (In)Formação) - Universidade Federal da Bahia, 2011. Disponível em: <https://repositorio.ufba.br/ri/bitstream/ri/13007/1/ Disserta\%C3\%A7\%C3\%A3o\%20de\%20Josevandro\%20Chagas\%20Soares.pdf>. Acesso em: 25 mar. 2016. 
SOUZA, A. da C. Comemorações e fotografias: práticas de inovação pedagógico-cultural e os afro-brasileiros na escola Maria Teófila - Amélia Rodrigues - Bahia. 2008. Dissertação (Programa de Pós-Graduação em Educação, subárea: Memória e Pluralidade Cultural) - Universidade do Estado da Bahia, 2008. Disponível em: <http://www.cdi. uneb.br/pdfs/educacao/2008/amos_da_cruz_souza.pdf $>$. Acesso em: 24 jul. 2016.

SOUZA, E. P. de. Tamborizar: história e afirmação da autoestima das crianças e adolescentes negros e negras através dos tambores de congo. 2005. Dissertação (Programa de Pós-Graduação em Educação, subárea: Pluralidade Cultural) - Universidade do Estado da Bahia, 2005. Disponível em: <http://www.cdi.uneb.br/pdfs/educacao/2005/ eileuza_penha_de_souza.pdf $>$. Acesso em: 25 mar. 2016.

SOUZA, J. C. P. de. Currículo e diversidade étnico-racial na materialidade da lei 10.639/2003 em duas escolas da rede municipal de contagem. 2011. Dissertação (Programa de Pós-Graduação em Educação, subárea: Educação Escolar e Profissão Docente) - Pontifícia Universidade Católica de Minas Gerais, 2011. Disponível em: <http://www. biblioteca.pucminas.br/teses/Educacao_SouzaJC_1.pdf>. Acesso em: 25 mar. 2016.

SOUZA, M. V. de S. Entre ajuricaba(s) e zumbi(s): currículo e diversidade cultural - a inclusão das temáticas culturais de matrizes indígenas e africanas na área de artes em escolas públicas da zona leste da cidade de São Paulo. 2010. Tese (Programa de Pós-Graduação em Educação, Subárea: Currículo) - Pontifícia Universidade Católica de São Paulo, 2010. Disponível em: <http://www.sapientia.pucsp.br/tde_busca/arquivo. php?codArquivo=12371>. Acesso em: 3 abr. 2016.

VALE, E. R. F. do. Capoeranças em verso e prosa: imagens da força matrial afro-ameríndia em literaturas da capoeira angola. 2012. Dissertação (Programa de Pós-Graduação em Educação, subárea: Cultura, Organização e Educação) - Universidade de São Paulo, 2012. Disponível em: <http://www.teses.usp.br/teses/disponiveis/48/48134/ tde-26112012-111712/pt-br.php>. Acesso em: 31 dez. 2016.

VIDON, G. R. O. N. A narratividade do hip hop e suas interfaces com o contexto educacional. 2014. Tese (Programa de Pós-Graduação em Educação, subárea: Educação e Linguagem: Verbal e Visual) - Universidade Federal do Espírito Santo, 2014. Disponível em: <http://repositorio.ufes.br/bitstream/10/1175/1/Tese.Geyza\%20Rosa.texto.pdf $>$. Acesso em: 3 mar. 2016.

\section{Artigos analisados}

AKKARI, A.; SANTIAGO, M. A questão da diversidade cultural no contexto educacional brasileiro. Revista Educação em Questão, Natal-RN, v. 38, p. 9-33, maio/ago. 2010. Disponível em: <http://www.periodicos.ufrn.br/educacaoemquestao/article/ view/4025/3292>. Acesso em: 23 set. 2016.

APPLE, M. W. Educação, mercado e culturas de controle. Revista E-Curriculum, São Paulo, v. 2, n. 3, dez. 2006. Disponível em: $<$ http://revistas.pucsp.br/index.php/curriculum/article/view/3152/2083>. Acesso em: 28 ago. 2016. 
BACKES, J. L. Negociações culturais e mudanças curriculares no Ensino Superior protagonizadas por sujeitos da etnia/raça afrodescendente. Revista Contrapontos, Itajaí-SC, v. 8, n. 8, p. 449-461, set./dez. 2008. Disponível em: <http:/www6.univali.br/seer/index. $\mathrm{php} / \mathrm{rc} /$ article/view/965. Acesso em: 5 set. 2015.

BACKES, J. L. Os estudos étnico-raciais e a ressignificação do currículo da educação básica. Revista Contrapontos Eletrônica, v. 13, n. 1, p. 15-23, jan./abr. 2013. Disponível em: <http://siaiweb06.univali.br/seer/index.php/rc/article/view/3865/2462>. Acesso em: 5 set. 2016.

CAETANO, A. A cultura do samba na prática educativa da geografia: uma proposta para implementação da lei. 10.639/2003. Revista $A B P N$, v. 3, n. 6, p. 113-130, nov. 2011fev. 2012. Disponível em: <http://www.abpn.org.br/Revista/index.php/edicoes/article/ view/210/153>. Acesso em: 22 jul. 2015.

COELHO, W. de N. B.; SILVA, R. M. de N. B. e. A imagem negra emoldurada na escola: sob o discurso da igualdade. Revista Reflexão e Ação, v. 18, n. 1, p. 100-124, 2010. Disponível em: <http://online.unisc.br/seer/index.php/reflex/article/view/1271 >. Acesso em: 14 out. 2015.

CUNHA JÚNIOR, H. Geometria, geometrização e arte afro-islâmica. Revista Teias (Os 10 anos da Lei 10.639/2003 e a Educação), v. 14, n. 34, p. 102-111, 2013. Disponível em: $<$ http://www.periodicos.proped.pro.br/index.php/revistateias/article/view/1577/1184>. Acesso em: 29 jan. 2016.

FARINA, S. Pedagogia de mandinga*: a capoeira escolar e no mundo da rua. Revista Didática Sistêmica, v. 13, n. 2, p. 94-106, 2011. Disponível em: <http:/www.seer.furg. br/redsis/article/view/2342>. Acesso em: 29 jan. 2016.

FELIPE, D. A.; TERYA, T. K. Nota sobre as políticas em prol do ensino da história e cultura afro-brasileira e africana na educação escolar. Revista HISTEDBR Online, Campinas, n. 39, p. 250-266, set. 2010. Disponível em: $<$ https://www.fe.unicamp.br/revistas/ ged/histedbr/article/view/3410>. Acesso em: 29 jan. 2016.

FERREIRA, M. G.; SILVA, J. F. da. Perspectiva pós-colonial das relações étnico-raciais nas práticas curriculares: conteúdos selecionados e silenciados. Revista Teias (Dossiê Especial), v. 14, n. 33, p. 25-43, 2013. Disponível em: <http://www.periodicos.proped. pro.br/index.php/revistateias/article/view/1591/1158>. Acesso em: $1^{\circ}$ jan. 2016.

GABRIEL, C. T.; COSTA, W. da. Que "negro" é esse que se narra no currículo de história? Revista Teias, v. 11, n. 22, p. 93-112, maio/ago. 2010. Disponível em: <http://www.periodicos.proped.pro.br/index.php/revistateias/article/view/607>. Acesso em: 14 mar. 2016.

GOMES, N. L. Relações étnico-raciais, educação e descolonização dos currículos. Revista Currículo sem Fronteiras, v. 12, n. 1, p. 98-109, jan./abr. 2012. Disponível em: $<$ http://www.acaoeducativa.org.br/fdh/wp-content/uploads/2012/11/curr\%C3\%ADculo-e-rela $\% \mathrm{C} 3 \% \mathrm{~A} 7 \% \mathrm{C} 3 \% \mathrm{~B} 5$ es-raciais-nilma-lino-gomes.pdf $>$. Acesso em: 14 mar. 2016. 
GONÇALVES, M. das G.; ANTUNES, J. L. C. Projeto negro e negras em movimentos: relações étnico-raciais na escola e o debate sobre a lei 10.639/03. Revista Teias, Rio de Janeiro, ano 9, n. 18, p. 68-77) jul./dez. 2008. Disponível em: <http://www.e-publicacoes. uerj.br/index.php/revistateias/article/view/24045>. Acesso em: 14 mar. 2016.

KING, J. Educação, comunidade e relações étnico-raciais: experiências nos Estados Unidos e em Mali. Revista Eletrônica de Educação, v. 6, n. 2, p. 64-83, nov. 2012. Disponível em: <http://www.reveduc.ufscar.br/index.php/reveduc/article/view/563>. Acesso em: 22 jul. 2015.

LUFWANKENDA, E. A construção do saber científico baseado em Edgar Morin e a questão da educação africana. Caderno da Pedagogia, ano 3, v. 1, n. 5, p. 216-241, jan./ jul. 2009. Disponível em: <http://www.cadernosdapedagogia.ufscar.br/index.php/cp/ article/viewFile/122/73>. Acesso em: 22 jul. 2015.

MARTINS, M. F.; VARANI, A.; SANTOS, A. B. dos; ROCHA, L. A. F.; CORREA, M. A. Educação das relações étnico-raciais negras: atuação de professores da rede pública de ensino da região de Sorocaba - SP. Revista HISTEDBR On-line, Campinas, n. 52, p. 340-356, set. 2013. Disponível em: <https://www.fe.unicamp.br/revistas/ged/histedbr/ article/view/4981/4644>. Acesso em: 21 set. 2016.

NDIMANDE, B. S. Lutas docentes nas escolas públicas para negros na África do Sul pós-apartheid. Cadernos de Educação (Fae/PPGE/UFPel), Pelotas, v. 39, p. 37-60, maio/ago. 2011. Disponível em: <http://periodicos.ufpel.edu.br/ojs2/index.php/caduc/ article/viewFile/1527/1433>. Acesso em: 21 set. 2016.

OLIVEIRA, S. C.; MACHADO, V. C. A lei 10.639/2003 e a I Semana da Consciência Negra do Instituto Federal Goiano - Campus Morrinhos: um relato de experiências. Revista Educação Popular, Uberlândia, v. 9, p. 157-164, jan./dez. 2010. Disponível em: $<$ http:// www.seer.ufu.br/index.php/reveducpop/article/view/20139>. Acesso em: 18 abr. 2016.

ONOFRE, J. A. Repensando a questão curricular: caminho para uma educação anti-racista. Revista Práxis Educacional, Vitória da Conquista, v. 4, n. 4, p. 103-122, jan./ jun. 2008. Disponível em: <http://periodicos.uesb.br/index.php/praxis/article/viewFile/329/362>. Acesso em: 18 abr. 2016.

PONCIANO, D. D.; GEBRAN, R. A.; LUVIZOTTO, C. K. História e Cultura Afro-brasileira no currículo de história do $6^{\circ}$ ao $9^{\circ}$ ano da rede oficial do Estado de São Paulo. Revista Teoria e Prática da Educação, v. 14, n. 2, p. 103-112, maio/ago. 2011. Disponível em: < http://periodicos.uem.br/ojs/index.php/TeorPratEduc/article/view/16156/8750>. Acesso em: 18 jan. 2016.

PONTES, C.; MACEDO, E. Demandas raciais no Brasil e política curricular. Cadernos de Educação (Fae/PPGE/UFPel), Pelotas, v. 38, p.175-200, jan./abril. 2011. Disponível em: <http://periodicos.ufpel.edu.br/ojs2/index.php/caduc/article/viewFile/1547/1454>. Acesso em: 18 jan. 2016.

REGIS, K. E. Relações étnico-raciais e currículos escolares nas teses e dissertações em educação (1987-2006): desafios da inclusão da cultura negra nas práticas curriculares. 
Revista ABPN, v. 2, n. 3, p. 139-154, jul./out. 2011. Disponível em: <www.abpn.org. br/Revista/index.php/edicoes/article/download/215/131>. Acesso em: 11 ago. 2016.

REGIS, K. E. Educação não escolar de adultos e relações étnico-raciais. Revista E-curriculum, São Paulo, v. 5, n. 1, dez. 2009. Disponível em: <http://revistas.pucsp.br/ index.php/curriculum/article/view/3251/2169>. Acesso em: 11 ago. 2016.

RESTREPO, E.; ROJAS, A. Políticas curriculares em tiempos de multiculturalismo: proyectos educativos de/para afrodescendientes em Colombia. Revista Currículo sem Fronteiras, v. 12, n. 1, p. 157-173, jan./jun. 2012. Disponível em: <http://www.ram-wan.net/restrepo/documentos/politicas\%20curriculares-restrepo-rojas.pdf $>$. Acesso em: 10 set. 2016 .

RODRIGUES, C. A. L. A educação física escolar e LDB: assumindo a responsabilidade na aplicação das leis 10.639/03 e 11.645/2008. Revista África e Africanidades (Especial Afro-Brasileiras: Construindo e Reconstruindo os Rumos da História), ano 2, n. 7, nov. 2009. Disponível em: <http://www.africaeafricanidades.com.br/documentos/A_Educacao_\%20Fisica_escolar_e_LDB.pdf>. Acesso em: 10 set. 2016.

SANTANA, J. V. J. de; SANTANA, M. de; MOREIRA, M. A. Cultura, currículo e diversidade étnico-racial: algumas proposições. Revista Práxis Educacional, Vitória da Conquista, v. 9, n. 15, p. 103-125, jun./dez. 2013. Disponível em: <http://periodicos. uesb.br/index.php/praxis/article/view/1945>. Acesso em: 17 nov. 2016.

SANTOS JÚNIOR, R. N. Afrocentricidade e educação: os princípios gerais para um currículo afrocentrado. Revista África e Africanidades, ano 3, n. 11, nov. 2010. Disponível em: <http://www.africaeafricanidades.com.br/documentos/01112010_02.pdf>. Acesso em: 16 nov. 2016.

SANTOS, R. A. dos; COELHO, W. de N. B. História e Cultura Afro-Brasileira no Ensino Fundamental: mito ou realidade? Revista da $A B P N$, v. 3, n. 7, p. 29-51, mar./ jun. 2012. Disponível em: <http://www.abpn.org.br/Revista/index.php/edicoes/article/ view/249/205>. Acesso em: 16 nov. 2016.

SANTOS, R. A. dos; COELHO, W. de N. B. Políticas curriculares e relações raciais no Brasil: entre textos e discursos. Revista Teias (Linguagens, Formação de Leitores e Cognição), v. 15, n. 38, p. 122-146, 2014. Disponível em: <http://www.academia. edu/10018428/POLITICA_CURRICULAR_E_RELA $\%$ C3\%87\%C3\%95ES_RACIAIS_NO_BRASIL $>$. Acesso em: 20 set. 2015.

SILVA, I. S. da. As inquietações no currículo educacional a partir da lei 10.639/03. Revista Padê, Brasília, v. 1, n. 2, p. 33-51, jul./dez. 2007. Disponível em: <http://www. journals4free.com/link.jsp?1=37006672>. Acesso em: 12 dez. 2015.

SILVA, M. V. O enfoque do negro no currículo escolar: algumas possibilidades de ressignificação. Revista de Educação Popular, Uberlândia, n. 3, p. 12-18, setembro, 2004. Disponível em: <http://www.seer.ufu.br/index.php/reveducpop/article/view/20004>. Acesso em: 12 dez. 2016. 
SILVA, M.; PEREIRA, M. M. Apontamentos sobre a lei 10.639 e o ensino de literatura: uma proposta de estudo. Revista Poiésis/UNISUL, Tubarão-SC, v. 8, n. 14, p. 488-495, jul./dez. 2014. Disponível em: <http:/www.portaldeperiodicos.unisul.br/index.php/ Poiesis/article/view/1428>. Acesso em: 12 dez. 2016.

SILVA, P. V. B. da; ARAÚJO, D. C. de. Educação em direitos humanos e promoção da igualdade racial. Revista Linhas Críticas, Brasília, v. 17, n. 34, p. 483-505, set./dez. 2011. Disponível em: <http://periodicos.unb.br/index.php/linhascriticas/article/view/6241>. Acesso em: 23 abr. 2016.

SILVA, W. R. P. da. Multiculturalismo e minorias negras: uma reflexão necessária para a educação. Revista África e Africanidades, ano 3, n. 12, fev. 2011. Disponível em: $<$ http://www.africaeafricanidades.com.br/documentos/12022011_18.pdf >. Acesso em: 23 abr. 2016.

SODRÉ, J. O design da alma - o legado do aze dos mestres e mestras dos saberes e fazeres afro-brasileiro. Revista África e Africanidades, ano 2, n. 6, agosto, 2009. Disponível em: $<$ http://www.africaeafricanidades.com.br/documentos/O_design_da_alma. pdf $>$. Acesso em: 23 set. 2016.

TEIXEIRA JÚNIOR, J. C. Por um afro-cotidianeidade na educação escolar. Revista Currículo sem Fronteiras, v. 13, n. 2, p. 307-319, maio/ago. 2013. Disponível em: <http:// www.curriculosemfronteiras.org/vol13iss2articles/teixeira.pdf $>$. Acesso em: 23 set. 2016.

UBERTI, H. G. A lei 10.639/03, possíveis diálogos. Revista Eletrônica História em Reflexão, UFGB - Dourados, v. 6, n. 12, p. 1-19, jul./dez. 2012. Disponível em: $<$ http:// www.periodicos.ufgd.edu.br/index.php/historiaemreflexao/article/view/2121/1176>. Acesso em: 23 set. 2016.

Texto recebido em: 29 de dezembro de 2017. Texto aprovado em: 30 de dezembro de 2017. 